\title{
Ensayos de caracterización del comportamiento frente al agua de la piedra natural
}

\section{Tests to characterize the behaviour of natural stone in contact}

Fecha de recepción: 8-X-01

Fecha de aceptación: 23-XI-01

\author{
with water \\ C. VIELBA CUERPO(*), F. HERNÁNDEZ OLIVARES(*) \\ (*)Dpto. de Infraestructura, Sistemas Aeroespaciales y Aeropuertos. E.U.I.T. Areronáutica. U.P.M.
} (“)Dpto. de Construcción y Tecnología Arquitectónica. E.T.S. Arquitectura de Madrid. U.P.M.

ESPAÑA

\begin{abstract}
RESUMEN
Se expone la necesidad de revisión de las normas UNE de ensayo para la determinación del comportamiento frente al agua de las rocas porosas teniendo en cuenta las formas de exposición que suponen las distintas aplicaciones constructivas y los mecanismos de penetración del agua que en cada caso operan. Se propone para ello una sistemática de ensayos y un método comparado de análisis de resultados basado en la consideración de los factores climatológicos. La utilidad del método se ilustra con un ejemplo de aplicación al estudio de la Arenisca de Villamayor
\end{abstract}

\section{SUMMARY}

This paper presents an experimental analysis of the stone behaviour in contact with water in the different construction uses. In any of these cases is analyse how the water penetrates into the material. As a result of the study the need of modification of the UNE test standards is concluded. It is proposed a procedure to determinate the material's properties and a method to compare and analyse the result obtained that keep into consideration the climate factors. The method have been applied to sandstone of Villamayor (Spain) showing its utility in the analysis of the stone properties.

\section{INTRODUCCIÓN}

La forma en que un material se comporta en contacto con el agua es una característica importante, por la influencia que la absorción puede tener en la modificación de propiedades.

Si consideramos, por ejemplo, las rocas naturales vemos que existen dos grupos con comportamientos bien diferenciados. Por un lado están las rocas de baja porosidad accesible, como los granitos y mármoles, en las que se registran absorciones totales bajas que no producen alteración en las propiedades. Por otro están las rocas de alta porosidad accesible, como ciertas calizas y areniscas, en las que la

\section{INTRODUCTION}

Water absorption can produce modifications in the properties of the materials. So, the behaviour of any material in contact whit water must be considered one of their principal characteristics.

In the natural stones for example there are two groups with very different behaviours. On the one hand they are the stones with low accessible porosity, as the granite and marble, that show a low water absorption with no changes in their properties. On the other hand they are the stones with high accessible porosity, as some sandstone and limestone, that have a high water absorption. These stones show in many cases 
absorción puede llegar a ser muy alta y determina la modificación de propiedades tales como la dureza o las resistencias mecánicas.

Aunque habitualmente se considera a las segundas de calidad inferior, existen rocas porosas que, aplicadas correctamente, constituyen un excelente material de construcción. El objetivo de este estudio es demostrar la importancia que, en este caso, tiene la determinación detallada y precisa del comportamiento del material en contacto con el agua.

\section{LA CARACTERIZACIÓN DE LAS ROCAS Y EL MARCO NORMATIVO}

Para estudiar con profundidad el comportamiento frente al agua de las rocas porosas es preciso definir una sistemática de ensayos específica, diferente de la de las rocas compactas, y aquí nos encontramos con la primera dificultad: la normativa a aplicar.

En España las normas de ensayo para rocas las elabora y publica AENOR a través de su comité 22 . Hasta hace un par de años estaban en vigor normas UNE elaboradas en 1985 que consideraban por separado los granitos, los mármoles y calizas ornamentales y las pizarras (1), y que eran de exclusiva aplicación en España. La libre circulación de productos en la Comunidad Europea obliga, sin embargo, a una armonización, con la asunción, en cada país, de las normas europeas (EN) elaboradas por el Comité Europeo de Normalización.

En diciembre de 1999 se publicaron una scrie de normas UNE-EN, entre las que se encuentran las relativas a comportamiento frente a humedad y determinación de resistencias mecánicas, que sustituyeron a las correspondientes de 1985. Estas normas no hacen distinción entre tipos de rocas, sino que son de aplicación general a cualquier clase de piedra natural (2).

No obstante, ni las normas de 1985 ni las de 1999 tienen en cuenta las especiales características de las rocas porosas. Por ejemplo, en las primeras, las resistencias mecánicas se determinan con probetas embebidas en agua tras 48 horas de inmersión. En las segundas se utilizan probetas desecadas en estufa y estabilizadas 24 horas en laboratorio. En el caso de las rocas porosas ninguno de los dos métodos es adecuado.

Un estudio riguroso debe analizar el comportamiento frente al agua ampliamente y no mediante valores aislados (las normas de 1985 proponían la determinación exclusiva de la absorción total por inmersión y las de 1999 la del coeficiente de absorción por capilaridad), ya important modifications in their properties, as in the hardness and in the mechanical strength.

Sometimes the second group of stones are considered no so good as the first. Nevertheless there are porous rocks that are a excellent construction material. The goal of this study is to show how important is to determinate the exact behaviour of these porous rocks in contact with water.

\section{THE CHARACTERIZATION OF STONES AND THE NORMATIVE FRAMEWORK}

To study the behaviour of porous rocks in contact with water is necessary to establish a specific program of test methods, different than the program applied to the compact rocks. For this we must know which test standards can be applied.

In Spain the test standards procedures for stones are elaborated and published by the 22 committee of AENOR. Two years ago there were in force standards elaborated in 1985. These were applied just in Spain and established different test methods for the different types of stones: granite, marble, limestone and shale (1). Nevertheless today is necessary to harmonize the standards of the different countries of the European Community establishing common European norms (EN). These are elaborated by the European Committee for Standardization.

Step by step Spain is assuming these European standards. In december 1999 there were published a group of UNE-EN standards for stones that derogated those from 1985. The new standards can be applied to any kind of stones and establish the method to determinate the mechanical properties and the stone behaviour in contact with water (2).

Nevertheless, the UNE standards, same these from 1999 than those from 1985, have not keep into consideration the special characteristics of the porous rocks. For example, the test methods from 1985 to determinate the mechanical properties use moist samples after 48 hours of water immersion. The test methods from 1999 use samples dried in the stove and keeping after in the laboratory during 24 hours. Porous rocks require a different consideration.

To establish the moisture that must contain the samples use in the determination of the mechanical properties is necessary to analyse first the stone behaviour in contact with water. This analyse must be done in depth and not obtaining only some separate 
que, para definir objetivamente el contenido de humedad que deben tener las probetas utilizadas en la determinación de propiedades, es preciso conocer los límites de absorción correspondientes a las distintas formas de exposición al agua. Además, es necesario relacionar cada aplicación constructiva con la forma de exposición que conlleva, teniendo presentes los mecanismos de penetración que en ese caso operan.

\section{PENETRACIÓN DELAGUA EN LOS MATERIALES POROSOS}

Adsorción de vapor de agua por higroscopicidad. Es la capacidad de un material, sometido a unas determinadas condiciones de temperatura y humedad relativa, de captar y retener vapor de agua en su red capilar. La naturaleza del material y el tamaño y forma de sus poros determinan que, en el proceso, tenga lugar una mayor o menor captación de vapor, que se produzca la condensación en la superficie del poro o que se rellene éste completamente de agua líquida.

Succión del agua líquida. Es la capacidad de un material, que se encuentra en contacto superficial con el agua, de absorberla por capilaridad, debido a las interacciones que se producen entre las tres fases implicadas. En virtud de ello el agua avanza por la red porosa, siendo la penetración total y la velocidad del proceso dependientes de la naturaleza del material y de la geometría y rugosidad de la red capilar.

Penetración del agua líquida bajo presión. Es la capacidad de absorción debida a la acción conjunta de la presión hidrostática y la succión. Si la presión es pequeña la importancia de ambos mecanismos es pareja. A medida que aumenta la presión el agua penetra fundamentalmente bajo la acción de la carga hidrostática, aunque parte de la misma se pierde cn vencer las resistencias debidas al rozamiento con las paredes del poro y a los cambios de sección, dirección o derivaciones de la red capilar.

\section{EXPOSICIÓN DE LA PIEDRA AL AGUA EN LAS CONSTRUCCIONES}

La necesidad de analizar el comportamiento frente a humedad de una roca viene determinada por el uso que se vaya a dar a la misma. Algunas formas constructivas no conllevan contacto directo con el agua (revestimiento de paredes interiores, por ejemplo), mientras que otras suponen exposiciones permanentes a la humedad ambiental, el agua de lluvia, etc.

Estas formas de contacto picdra-agua pucden resumirse de la siguiente manera: values. (The 1985 test standards determinate just the total absorption by water immersion. The 1999 test standards determinate the absorption by capillarity when the stone is in superficial contact with water). Also any construction application must be considered in correspondence with the ways of exposure to the water that it suppose. By the way they must be known the models of water penetration that work in any case.

\section{WATER PENETRATION IN POROUS MATERIALS}

\section{Water vapor absorption by hygroscopycity. It means the capacity of the material, in some external conditions of humidity and temperature, for wining and keeping water vapour in its capillary net. The amount of vapour win depend on the nature of the material and on the shape and size of the pores. In some materials the vapour can become condensed over the pore surface and sometimes the pore can become full of liquid water.}

Liguid water suction. It means the capacity of the material, that is in superficial contact with liquid water, for absorbing it by capillarity forces. It is due to the interaction between the three phases involved in the process. As a result of this, the water penetrates in the pores. The speed and the level of water penetration is a consequence of the material's characteristics and of the pore's geometry and roughness.

Liquid water penetration under pressure. It means the capacity of the material to absorb water due to the hydrostatic pressure and the suction. With a low pressure both mechanisms behave likely. When the water pressure is high the material absorb water principally due to this pressure. Nevertheless a part of the pressure is wasted in overcoming the resistance offered to the water advance by the friction with the pore surface and by the changes of size, direction or derivation of the porous net.

\section{THE STONE EXPOSURE TO THE WATER IN BUILDINGS CONSTRUCTION}

The analysis of the stone behaviour in contact with water must be short or extensive depending on the construction use expected for the stone. Some constructive uses do not involved contact with water (veneering of interiors walls, for example). But others involve permanent contact with the vapour or casual contact with the rain.

The ways of contact between the stone and the water can be: 
Humedad ambiental. Deben considerarse dos casos diferentes:

- Acción directa del vapor de agua atmosférico: penetración por HIGROSCOPICIDAD.

- Condensación del vapor de agua atmosférico en superficie.

Como la piedra es un material de baja conductividad y alta inercia térmicas, en determinadas condiciones ambientales puede presentar superficie de contacto fría, produciéndose la condensación sobre ella del agua atmosférica que penetra por SUCCIÓN.

Acción directa del agua de lluvia. Hoy en día la piedra se usa principalmente para revestimientos. Cuando esta aplicación se realiza en exteriores cabe distinguir dos casos:

- En fachadas, si no actúa el viento, se produce un contacto simple con el agua, que penetra por SUCCIÓN. Si sopla el viento, presionando al agua contra la pared, actúan los mecanismos de SUCCIÓN y PENETRACIÓN DEL AGUA BAJO PRESIÓN.

- En pavimentos el agua actúa bajo la presión de la gravedad, además, tras fuertes aguaceros $\mathrm{u}$ obstrucciones a la circulación del agua, pueden producirse acumulaciones, en cuyo caso actúa la presión debida a la altura geométrica de la columna de agua. En estos casos se combina la SUCCIÓN con la PENETRACIÓN DEL AGUA BAJO PRESIÓN.

Humedad contenida en los terrenos. En los zócalos el material puede encontrarse en contacto directo con terrenos húmedos por la presencia próxima del nivel freático. La piedra absorberá en este caso el agua por capilaridad ascendente, es decir, por SUCCIÓN.

\section{PROPUESTA DE ENSAYOS PARA ROCAS POROSAS}

En los materiales porosos es importante analizar cómo actúa cada uno de los mecanismos de absorción. Para ello deben utilizarse métodos de ensayo que reproduzcan las condiciones reales de exposición al agua. Se da a continuación una lista de ensayos propuestos indicando con un asterisco aquéllos para los que no existe norma de referencia.

Higroscopicidad*. Se propone el ensayo en cámara húmeda de probetas cúbicas sometidas a distintas condiciones de temperatura y humedad relativa.

Datos a obtener: gráficas de variación del contenido de humedad, en $\%$, con el tiempo.
Environmental humidity. Two cases must be considered:

- The action of the atmospheric water vapour involve the absorption by HYGROSCOPYCITY

- The condensation of the atmospheric water vapour over the stone surface involve the absorption of the condensed water by SUCTION.

As the stone has a low thermal conductivity and high thermal inertia, in some external conditions it have a could surface. That produces the vapour condensation.

Rain water action. The stones are used now principally for veneering. When they are used in external walls we can distinguish different rain actions over the veneers:

- When there is not wind the rain just contact with the façades penetrating by SUCTION. When the wind blow, it press down the rain on the walls. Then the water penetrates by SUCTION and UNDER THE WIND PRESSURE.

- Over the floors the rain act always under the gravity pressure. But the water can be also accumulated over the floor due to obstructions to their circulation after strong showers. In this case the stone pavements are under the pressure of the water. So the rain penetrates in the floors by SUCTION and UNDER THE WATER PRESSURE.

Humidity contained in grounds. The foundations of walls can be in contact with moist grounds. In this case the stone absorbs the water by upward capillarity, it means, by SUCTION.

\section{PROPORSAL OF TEST METHODS FOR POROUS ROCKS}

When we study the porous rocks it is very important to know how the water absorption works in any case of exposure to water. The test method used in any of this cases must reproduce the real conditions of the exposure. We propose for this the next list of tests. The asterisk point the tests with no standard reference.

Hygroscopicity*. Cubic samples are subject to different conditions of humidity and temperature in a damp chamber.

Information to obtain: graphs of the change of moisture content (\%) at any time. 
Succión. Para este ensayo puede utilizarse una bandeja como la representada en la figura 1. La probeta apoya en dos guías, quedando su superficie inferior en contacto con el agua. El nivel se mantiene por aporte continuado y evacuación a través de un rebosadero.

En la succión el proceso de absorción se desarrolla en dos fases. La primera va del instante cero al instante en el que la humedad alcanza la cara superior. La segunda corresponde al avance del agua, una vez llena la red capilar principal, por los poros menos accesibles. La primera fase es más rápida y la absorción total en la misma es muy superior a la de la segunda. La obtención de datos debe tener en cuenta la existencia de estas fases.

\section{Datos a obtener:}

- Coeficiente de absorción por capilaridad (UNE-EN 1025:1999)

Es la pendiente de la primera rama de la gráfica que relaciona la absorción, en gramos por $\mathrm{m}^{2}$ de superficie expuesta, con la raíz cuadrada del tiempo, en $\mathrm{s}^{0,5}$.

Corresponde a la primera fase de absorción e indica la rapidez con la que ésta se produce.

- Tiempo invertido en la primera fase para distintos espesores de probeta*, elaborando una gráfica espesor/tiempo que permita evaluar el avance del frente húmedo por el material.

Penetración del agua líquida bajo presión. Pueden seguirse dos métodos de ensayo:

Ensayo de inmersión. La absorción se produce por succión y bajo la presión de la columna de agua. El frente húmedo avanza desde la superficie lateral hacia el núcleo interior (figura 2).

Datos a obtener:

- Absorción total a un tiempo dado (UNE 22-182-85/ anulada).

- Gráficas de variación del contenido de humedad, en $\%$, con el tiempo, en minutos, determinando los cambios significativos en la pendiente de la curva*

En este proceso de absorción se observan las mismas fases que en la succión: primero el agua avanza por la red capilar principal humectando la probeta; a continuación sigue por los poros menos accesibles. En la gráfica el paso de una fase a otra se aprecia por una
Suction. We propose to use for this test the tray draft in the figure 1. The sample lay over two linear supports being its lower surface in superficial contact with the water. The liquid level is maintaining by a continuous water contribution and by a overflow evacuation.

The suction process shows two phases. The first phase start at the zero time and end when the moisture reach the upper surface of the sample. Next, in the second phase, the water, after to fill the main porous net, continue the advance by the thinnest pores. The first phase is quicker than the second and shows a higher total absorption. To obtaining facts from the test is necessary to consider the existence of the two phases.

\section{Information to obtain:}

- Absorption coefficient of capillarity (UNE-EN

1025:1999). This is the slope of the first section of the graph that relate the absorption, in grams per square meter of exposed surface, to the square root of the time $\left(s^{0,5}\right)$. It correspond to the first phase of absorption and indicate the speed of this.

- Time spend in the first phase considering different thick of samples*. With this information we can made a graph thick/time to evaluate the speed advance of the moist face.

Liquid water penetration under pressure. We propose two test procedures:

Immersion test. In this case the absorption is due to the suction and to the hydrostatic pressure. The moisture advance from the side faces to the interior core (figure 2).

\section{Information to obtain:}

- Total absorption in different test periods (UNE 22182-85/revoked)

- Graphs of the moisture content (\%) at every single time of the test (minutes), obtaining the outstanding slope changes in the graph*.

In this absorption process we can observe the same phases than in the suction process. First the water advance by the main porous net filling the sample. Next it advance by the thinnest pores. The slope changes in
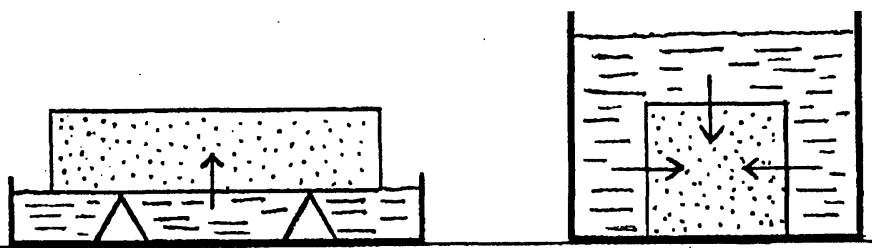

Figuras 1 y 2.- Ensayos de succión e inmersión. Las flechas indican el avance del agua absorbida.

Figures 1 and 2.- Suction and immersion tests. The arrows show the advance of the absorbed water. 
disminución de la pendiente debida al cambio de velocidad de absorción.

- Hinchamientos debidos a la absorción de agua* . Se propone un ensayo con probetas prismáticas utilizando un reloj comparador acoplado a un soporte (figura 3).

Ensayo de permeabilidad*. Se propone la utilización del dispositivo representado en la figura 4. Consiste en un recipiente de metacrilato colocado sobre la probeta de modo que ésta constituya el fondo del mismo. La unión entre ambos se sella con silicona y el conjunto se eleva sobre dos apoyos. El sistema permite ensayar probetas de distinto espesor y aplicar distintas alturas de columna de agua, cuyo nivel debe mantenerse rellenado periódicamente.

\section{Datos a obtener:}

- Tiempo hasta humectación total de cara inferior y contenido de humedad en ese instante.

- Determinación, por observación, del momento en que el agua rezuma por la cara inferior.

De los ensayos expuestos unos representan mejor que otros la exposición real de la piedra al agua en las construcciones. Por ejemplo, la inmersión sólo es posible en muros enterrados bajo el nivel freático, algo que la buena práctica constructiva recomienda evitar. Sin embargo este ensayo aporta datos necesarios para explicar cómo se produce la absorción de agua líquida.

Acabado el estudio y establecidos los contenidos de humedad de las distintas fases de absorción, se puede diseñar el plan de ensayos para la determinación de las restantes propiedades. Obtenidas éstas, y para extraer conclusiones referentes a la aptitud de la piedra, es necesario considerar todavía otro factor: las condiciones ambientales de utilización.

\section{EL EFECTO DE LA CLIMATOLOGÍA}

En principio no hay por qué rechazar una piedra porque presente altas absorciones y bajas resistencias en estado húmedo. Siempre habrá aplicaciones y situaciones the graph, dues to the changes in the absorption speed, show the transition into the phases.

- Samples enlarges dues to the water absorption*. We propose a test procedure using prismatic samples placed into the water and a comparison clock hold up by a support (figure 3).

Permeability test*. For this test we propose to use the device of the figure 4. It consist in a polymethacrylate recipient put over the sample so that the stone was its bottom. The union between the sample and the recipient must be sealed with silicon. The unit must be elevated over two supports. This procedure allow to test samples of different thickness with different dept of water column. The water level must be keeping by filling regularly.

\section{Information to obtain:}

- Time till total moist of the sample lower surface and moisture content at that moment.

- Determination, by regular observation, of the time at which the water oozes by the lower surface.

Some of the test showed represent better than the others the real stone exposure to water in the different construction uses. For example, the immersion is only possible in the case of the walls buried under the water table.

Nevertheless, it is a good construction standard to avoid this case. However this test bring useful information to understand the process of the water absorption.

The test plan to obtain the rest of the stone properties must be designed after establishing the moisture contents of the different absorption phases. When the whole study was finished, it will be necessary to consider any other factor to come to conclusions: the environmental conditions in which the stone will be used.

\section{THE CLIMATOLOGY EFFECT}

A stone with high water absorption and low strength when it is moist, must not be considered a bad construction material. There will be some suitable environmental conditions and

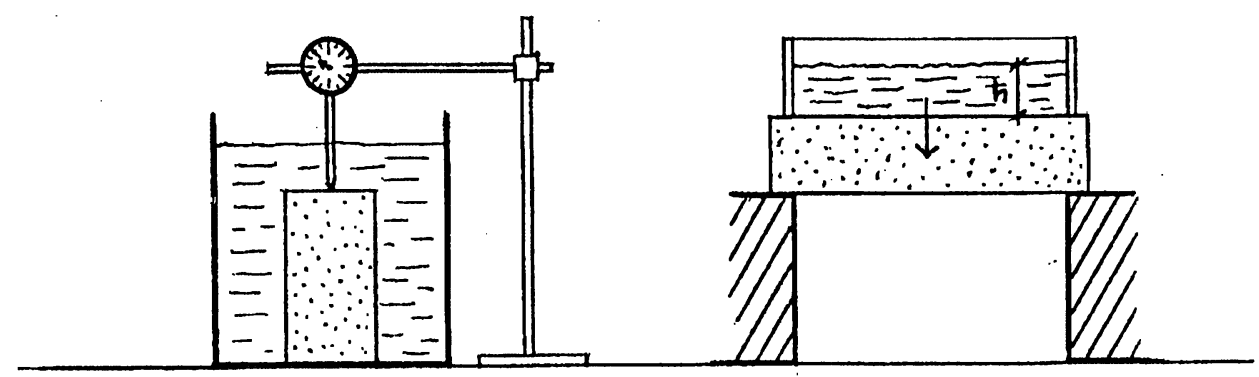

Figuras 3 y 4.- Ensayo para determinación de los hinchamientos y ensayo de permeabilidad. Figures 3 and 4.- Test of determination of the enlarges and test of permeability. 
ambientales para las que resulte adecuada. En la mayoría de los casos es posible la utilización al exterior, condicionada a un estudio previo de la climatología de la zona. Este estudio debe considerar:

- Niveles de humedad relativa y temperatura

- Frecuencia de precipitaciones, duración e intensidad de las mismas.

- Velocidad media máxima del viento e intensidad de las rachas instantáneas.

A partir de estos datos pueden programarse ensayos de comprobación. Por ejemplo, puede determinarse la permeabilidad con una altura de columna de agua que represente la presión previsible de viento en la zona, actuando simultáneamente a la lluvia, sobre una fachada.

Comparando los datos climatológicos y cl resultado de los ensayos de caracterización, se puede establecer si la piedra es idónea o no para ese clima, y qué usos y formas constructivas son los más adecuados.

\section{CONCLUSIONES}

A la vista de lo expuesto proponemos una revisión de las normas de ensayo para la piedra natural. Se recomienda, asimismo, que la interpretación de resultados y obtención de conclusiones se realice considerando las formas de exposición que suponen las distintas aplicaciones constructivas y la climatología de las áreas de posible aplicación del material.

El proceso se resume esquemáticamente a continuación:

- Estudio del comportamiento frente al agua de la piedra teniendo en cuenta los distintos mecanismos de penetración.

- Definición de los contenidos de humedad con los que deben determinarse las propiedades de la piedra basándose en el anterior estudio.

- Interpretación de resultados considerando:

- La relación entre aplicación constructiva y forma de exposición al agua.

- Los factores climatológicos.

- Conclusiones y recomendaciones.

\section{EJEMPLO DE APLICACIÓN DEL MÉTODO A LAARENISCA DE VILLAMAYOR}

Se presenta a continuación el estudio efectuado sobre la Arenisca de Villamayor siguiendo el método propuesto. Ésta es una roca eocénica de grano fino a muy fino constituida por arenas silíceas y feldespáticas cementadas por arcillas. Sus canteras principales se encuentran en la población de Villamayor, en las proximidades de la ciudad de Salamanca. uses that can be done to it. In many cases these stones can be used on the buildings outside. For this is necessary to study previously the climatology of the area in which the stone will be used. This study must consider:

- The humidity and the temperature levels

- The rainfall frequency, duration and intensity.

- The maximum wind speed and the strength of the snap gust.

Starting from these data it is possible to draw up a test programme to verify the stone suitability for being used in this area. For example we can test the permeability under a water column that represent the foreseeable wind pressure working together with the rain over the façades.

With the results of the tests made it can be known if the stone is suitable for a particular area by comparison of the tests data with the climatology data. Also it will be possible to establish the most suitable constructive uses.

\section{CONCLUSIONS}

According to what has been said above we propose a revision of the test standards for the natural stones. Also we suggest to analyse the test data and to come to conclusions by considering the climatology and the exposure to the water that the different construction uses involve.

\section{The process is resumed next:}

- Study of the stone behaviour exposed to the water by considering the different model of water penetration.

- Starting from those data it can be established the moisture content of the samples used in the determination of the stone's mechanical properties.

- The results of those tests must be analysed considering:

- The relationship between the construction uses and the ways of exposure to water.

- The climate factors.

- Final conclusions and suggestions.

\section{EXAMPLE OF APPLICATION OF THE EXPOSED METHOD TO THE ARENISCA DE VILLAMAYOR}

Next we expose the study made to the rock called Arenisca de Villamayor using the suggested method. This is a eocene sandstone fine to very-fined grain made up of quartz and feldespar sand cemented by clay. The main quarries are located in the village of Villamayor, next to the Salamanca city (Spain). 
La Arenisca de Villamayor es especialmente porosa (36,1\% de porosidad absoluta y $30,4 \%$ de porosidad abierta según los ensayos efectuados) y en estado saturado se ablanda y pierde resistencia de tal modo que algunos estudios realizados sobre la misma no han dudado en calificarla negativamente como material de construcción.

Sin embargo esta piedra ha sido utilizada durante siglos en Salamanca y es la que presta a la capital charra el color pardo-dorado que la caracteriza. Un paseo por el casco histórico demuestra además que el estado de conservación de los edificios en los que se ha evitado la acumulación de agua sobre la piedra, es muy bueno. Los resultados del estudio realizado ayudan a comprender el por qué de este comportamiento.

\section{Absorción por inmersión}

Con probetas cúbicas de $7 \mathrm{~cm}$ de lado se ha realizado un ensayo a 56 días obteniendo una absorción media total del $17,95 \%$. También se ha elaborado la curva absorción/tiempo (figura 5), en la que se aprecia una primera fase muy rápida en los primeros 20 minutos. Después la velocidad desciende $\mathrm{y}$, a partir de los 60 minutos, en los que se llega a un 13,63\% de absorción, el crecimiento de la curva se vuelve muy lento.

La transición de la fase rápida a la lenta se ha fijado en el instante en el que la pendiente desciende al $20 \%$, lo que ocurre a los 18 minutos, con una absorción media del $10,34 \%$.

\section{Adsorción de vapor de agua}

Se han utilizado probetas cúbicas de $7 \mathrm{~cm}$ de lado sometiéndolas, en armario húmedo, a unas condiciones ambientales de $20^{\circ} \mathrm{C}$ y $95 \%$ de humedad relativa.

La figura 5 muestra los 120 minutos iniciales de la gráfica contenido de humedad (\%) / tiempo(min) comparada con la del ensayo a inmersión. Como se ve, la adsorción de vapor es muy inferior a la absorción de agua líquida lo que indica que, en este caso, no se produce la condensación en el interior del poro.

\section{Hinchamientos por absorción de agua}

Utilizando el método propuesto con probetas prismáticas $(5 \times 5 \times 9 \mathrm{~cm})$ se han determinado las curvas hinchamiento/tiempo y absorción/tiempo (figura 6).

Con esta forma de probeta la primera fase de absorción dura 10 minutos, y en ella apenas se registran hinchamientos. Éstos tienen lugar en los 50 minutos siguientes, mientras el agua, una vez llena la red capilar principal, avanza por los poros más finos que, en este caso, son los del cemento arcilloso. A partir de los 60
The Arenisca de Villamayor is very porous $(36,1 \%$ of total porosity and 30,4\% of open porosity according with the tests made). When saturated in water it displays so spectacular loss in resistance and become so soft that in some studies the Arenisca de Villamayor has been qualified as a bad construction material.

Nevertheless this stone has been used during centuries in Salamanca, and it gives to the city its typical golden colour. $A$ walk around the centre town shows also a good maintenance of the buildings in which it has been avoid the water accumulation over the stone. The results of the study made help us to understand why the stone shows this good behaviour.

\section{Absorption by immersion}

We have immersed in water cubic samples, with sides measuring $7 \mathrm{~cm}$, during 56 days. The mean total absorption obtained has been 17,95\%. We have elaborated also the graph absorption/time (fig.5). The graph shows a very quickly absorption phase during the first 20 minutes. Next the speed decreased. After the first 60 minutes, when the moisture content rise to $13,63 \%$, the absorption grow very slowly.

The transition between the two phases has been establish at the moment in which the graph slope decreased till the 20\%. That happens at the minute 18 with a mean absorption of $10,34 \%$.

\section{Absorption of water vapour}

We have used cubic samples, with sides measuring 7 $\mathrm{cm}$. They have test in a damp chamber in conditions of $20^{\circ} \mathrm{C}$ of temperature and $95 \%$ of relative humidity.

The figure 5 shows the first 120 minutes of the graph moisture content (\%)/time (minutes) in comparison with the graph obtained in the test by immersion. As we can see the vapour absorption is to much lower than the liquid water absorption. That indicates that, in this case, there is not vapour condensation in the pores.

\section{Dilatation by water absorption}

We have elaborated the graphs length increase/time and absorption/time following the test procedure suggested that uses prismatic samples: $5 \times 5 \times 9 \mathrm{~cm}$ (figure 6).

With this sample shape the first absorption phase last 10 minutes and shows small length increases. The most important length increases happen in the next 50 minutes, while the water, once filled the main porous net, advance by the thinnest pores, those of the clay 


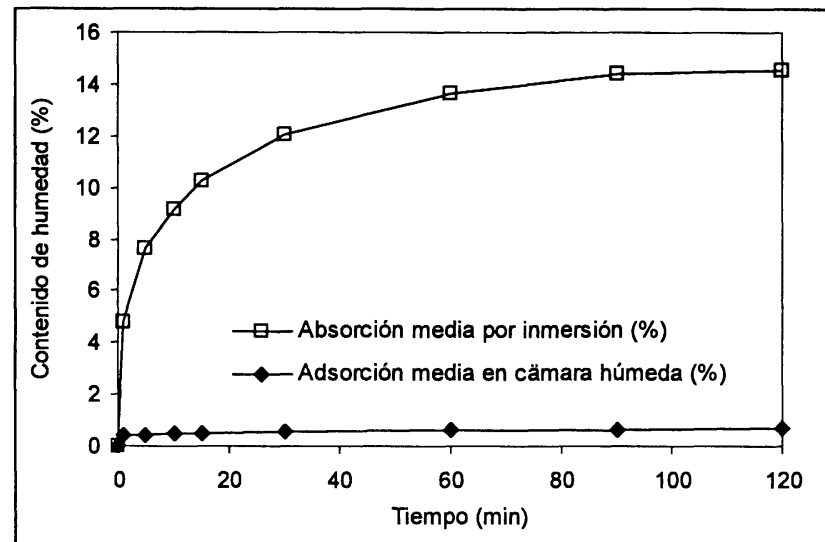

Figura 5.- Absorción por inmersión y en cámara húmeda (detalle de los 120 primeros minutos).

Figure 5.- Absorption by immersion and in damp chamber (detail of the first 120 minutes).

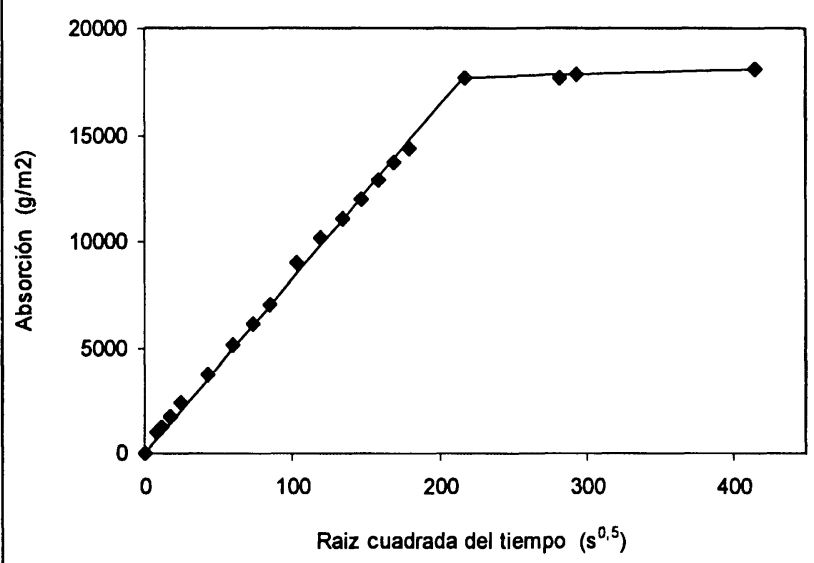

Figura 7.- Gráfica del ensayo a succión. Ajuste lineal.

Figure 7.- Graph of the suction test. Lineal fit.

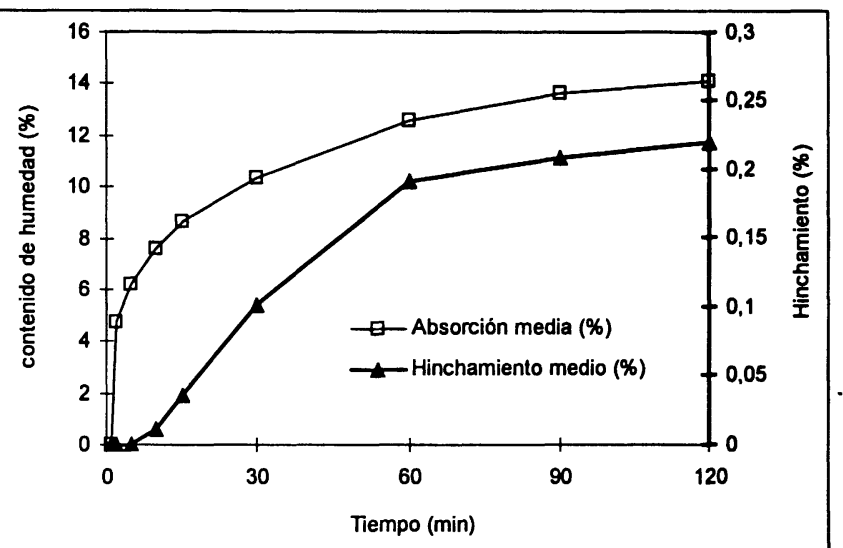

Figura 6.- Hinchamientos por absorción de agua (detalle de los 120 primeros minutos).

Figure 6.- Length increases by water absorption (detail of the first 120 minutes).

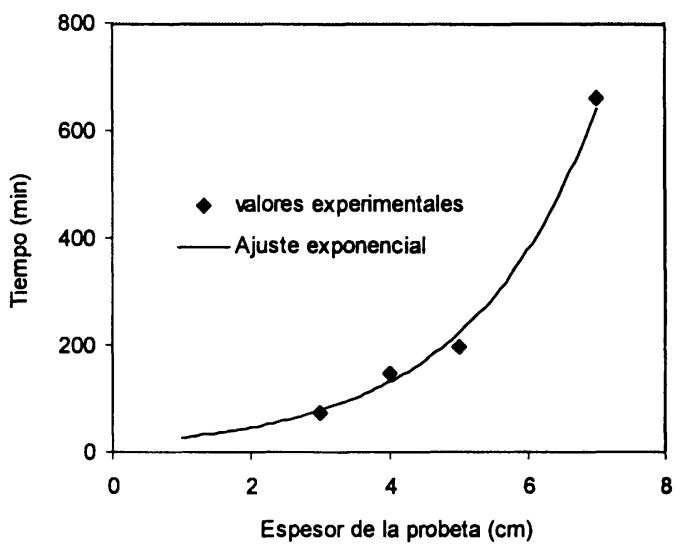

Figura 8.- Duración de la primera fase de la succión en ralación al espesor de probeta.

Figure 8.- Time spent in the first phase of suction related to the sample thickness. minutos, tanto la absorción como los hinchamientos progresan muy lentamente.

El hinchamiento a los 120 minutos es de $0,22 \%$, lo que debe ser tenido en cuenta en el diseño de juntas.

\section{Succión}

- Con probetas cúbicas de $7 \mathrm{~cm}$ de lado se ha determinado la absorción, en $\mathrm{g} / \mathrm{m}^{2}$, con relación a la raíz del tiempo, en $\mathrm{s}^{0,5}$, viendo que puede realizarse un ajuste lineal de los puntos obtenidos según dos rectas que representan las dos fases de absorción (figura 7). El coeficiente de absorción por capilaridad obtenido (pendiente de la primera recta) es de $97,23 \mathrm{~g} / \mathrm{m}^{2} \mathrm{~s}^{0,5}$, 10 que indica una velocidad alta de absorción en la primera fase.

- Con probetas prismáticas de espesores variable $(3,4$ 5 y $7 \mathrm{~cm}$ ) se ha determinado la duración de la primera fase (tiempo hasta humectación de la cara superior). El resultado se presenta gráficamente en la figura 8 donde cement. After the first 60 minutes the absorption, same than the length increases, grow very slowly.

The length increase after testing by 120 minutes is $0,22 \%$. That must be considered in the joints design.

\section{Suction}

- We have determined the absorption $\left(\mathrm{g} / \mathrm{m}^{2}\right)$ in relationship of the square root of the time $\left(s^{0,5}\right)$ using cubic samples, with sides measuring $7 \mathrm{~cm}$, and we had elaborated the correspondent graph. The points obtained can be fitting obtaining two straight lines that represent the two absorption phases (figure 7). The coefficient of water absorption by capillarity (slope of the first straight line) is $97,23 \mathrm{~g} / \mathrm{m}^{2} \mathrm{~s}^{0.5}$. It shows a high speed of absorption in the first phase.

- We have determined also the time spent in the first phase (time to moist the upper surface of the sample) using different prismatic samples with thickness measuring 3, 4, 5 and $7 \mathrm{~cm}$. The results are represented graphically in the figure 8 . The 
se puede comprobar que los puntos que relacionan espesor y tiempo pueden ajustarse mediante una curva exponencial que representa la disminución progresiva de la velocidad de avance del frente húmedo.

(Se han determinado también las absorciones en \% en un estudio a 48 horas, comparándolas con las del ensayo a inmersión, comprobando que los tiempos y contenidos de humedad de la segunda fase son análogos en ambos ensayos)

\section{Permeabilidad}

La Arenisca de Villamayor se usa hoy en día principalmente para el revestimiento de fachadas y su área fundamental de aplicación es Salamanca. Por ello se ha realizado el ensayo con una altura de columna de agua de $2 \mathrm{~cm}$, que representa la presión media de viento en la zona, en el período de lluvias. Ésta se ha obtenido aplicando la norma NBE AE-88 (3) y a partir de los datos de la publicación K-20 del Instituto Nacional de Meteorología (4).

Usando probetas de $3 \mathrm{~cm}$ de espesor se han obtenido tiempos de avance del frente húmedo y contenidos de humedad similares a los del ensayo a succión. Ello demuestra que, en este caso, el efecto de la presión es pequeño y que la absorción se produce principalmente por succión.

Tras 48 horas de ensayo se ha comprobado que, bajo las condiciones ambientales medias del laboratorio (20 ${ }^{\circ} \mathrm{C}$ y $58 \%$ de humedad relativa) se alcanza el equilibrio absorción-evaporación, lo que hace que el agua no rezume por la cara inferior.

\section{Conclusiones}

La Arenisca de Villamayor tiene una alta capacidad de absorción que se desarrolla en tres etapas: la primera, muy rápida, hasta rellenar la red capilar principal, momento en el que se alcanza un contenido de humedad en torno al $10 \%$; la segunda, más lenta, mientras el agua avanza por los capilares más finos hasta alcanzar aproximadamente un $13 \%$ de contenido de humedad y, por último, una etapa de absorción muy lenta y progresiva, por avance a través de los capilares más inaccesibles.

La duración de la primera etapa depende de la forma de exposición al agua y el grosor de la probeta. Sin embargo, una vez llena la red principal, la absorción progresa de forma similar en todos los casos.

Consecuentemente, al análisis del comportamiento frente a humedad se han realizado ensayos para determinar las restantes propiedades del material considerando 3 contenidos de humedad: points relate the sample thickness to the time spent in the first phase. They can be fitted by a exponential curve that represented the decreasing speed of the moist face advance.

(We have determined also the absorption increase, in percentage, by testing the samples during 48 hours. We have compared the results obtained with the data of the immersion test. Both shows similar moisture contents in the second phase)

\section{Permeability}

Today the Arenisca de Villamayor is principally employed as a veneer for façades. It is used specially in the Salamanca area. For this reason we have tested the stone permeability under a water column, measuring $2 \mathrm{~cm}$ high that represent the mean wind pressure in the area during the rain season. This pressure value has been obtained by using the NBE AE-88 standard (3) and from the data of the publication $K-20$ of the National Institute of Meteorology (4).

The times of the moist face advance and the moisture content obtained in the test by using samples measuring $3 \mathrm{~cm}$ thickness, are similar than those obtained in the suction test. That circumstance prove that, in this case, the effect of the wind pressure is not very important and the absorption is due principally to the suction.

We have tested the samples during 48 hours in the environmental conditions of the laboratory $\left(20^{\circ} \mathrm{C}\right.$ and $58 \%$ of relative humidity). In those conditions we have verified that there is a balance between the absorption and the evaporation and the water does not ooze by the lower surface of the sample.

\section{Conclusions}

The Arenisca de Villamayor has a high water absorption capacity showing three phases of absorption. The first is very quickly, while the water fill the main capillary net. The moisture content reach in this phase come near 10\%. The second phase is not so speed. In this the water advance by the thinness pores. The moisture content at the end of this phase is approximately 13\%. Finally the third phase shows a very slowly absorption while the water progress by the thinnest pores.

The time spent in the first phase depend on the way of exposure to water and on the sample thickness. Nevertheless, once filled the main capillary net, the absorption advance similarly in all the cases.

In addition to the analysis of the stone behaviour in contact with water we have made also tests to determinate the rest of the material's properties by considering three moisture contents: 
- Humedad de equilibro en las condiciones ambientales del laboratorio $\left(\mathrm{T}=20^{\circ} \mathrm{C} ;\right.$ H.R. $\left.=58 \%\right)$ :

aproximadamente $1 \%$.

- Límite de la primera fase de absorción:

aproximadamente $10 \%$.

- Límite de la scgunda fase de absorción:

aproximadamente $13 \%$.

Aunque no podemos exponer, por su extensión, todos los resultados del estudio, nos interesa destacar la importante disminución de dureza y resistencias que tiene lugar con el aumento del contenido de humedad y la baja resistencia a helada de la piedra (pérdida de masa de un $5,29 \%$ tras 25 ciclos, aunque resiste 12 ciclos antes de comenzar el deterioro).

Sin embargo, como ya apuntábamos antes, el patrimonio monumental de Salamanca prueba que la Arenisca de Villamayor resiste bien el paso del tiempo. Ello es debido a la relación entre el comportamiento de la piedra y las condiciones climatológicas a las que se encuentra expuesta.

Según las distintas clasificaciones meteorológicas el clima de Salamanca debe calificarse de "seco" (4), con una duración e intensidad de precipitaciones baja. Por ello, en fachadas, donde el agua de lluvia penetra por succión con velocidad exponencialmente decreciente (en dos horas y media el agua llega a una profundidad de $4 \mathrm{~cm}$ y en 11 horas a $7 \mathrm{~cm}$ ), el alcance del frente húmedo será pequeño y además retrocederá en cuanto cesen las lluvias y comience el secado. En estas condiciones, el que se produzca la total humectación de la piedra, o que el agua siga penetrando hasta saturar los capilares más finos, depende de los espesores utilizados.

Los resultados de los ensayos permiten, pues, establecer “a priori" los usos y sistemas constructivos más adecuados, aunque estos deban ser comprobados luego mediante ensayos específicos.

En conclusión, el ejemplo expuesto demuestra la utilidad del método al conducir a un mejor conocimiento del comportamiento de la piedra y permitir definir con mayor precisión cuáles son sus posibilidades de aplicación en el campo de la construcción.
- Balance moisture in the environmental conditions of the laboratory $\left(T=20^{\circ} \mathrm{C} ; R . H .=58 \%\right)$ : approximately $1 \%$

- Limit of the first absorption phase: approximately $10 \%$

- Limit of the second absorption phase: approximately $13 \%$

We can not show all the data obtained in the study, but we want to emphasise the outstanding loos of hardness and mechanical resistance that the increase of moisture content produces. Also we want emphasise the low frost resistance of the stone (Weight lost 5,29\% after 25 cycles. Nevertheless the stone resist 12 cycles before start the damage).

But, as we have said before, the building heritage of Salamanca prove that the Arenisca de Villamayor have a good resistance as time goes on. The resistance is due to the relationship between the stone behaviour and the climatic conditions of exposure.

In the different meteorology tables the Salamanca climate is classified as "dry" (4), with low rain intensity and duration. The rain water penetrates in the façades by suction with exponentially decreasing speed (The water spent two hours to reach $4 \mathrm{~cm}$ depth and eleven hours to reach $7 \mathrm{~cm}$ depth). So under the Salamanca climate the moisture will not reach large depths and it will decrease when the rain stopped and the stone started to dry. In those conditions the total moisture content of the stone, same than the water penetration by the thinnest pores, depend on the thickness of the veneers employed.

The test results allows us to establish initially the most suitable constructive uses although they have to be checked after, by specific tests.

The exposed example prove the benefits of the method as it give us a better known of the stone behaviour. It allows also to define most exactly the best constructive uses for any stone.

\section{BIBLIOGRAFÍA}

(1) UNE 22170:1985 "Granitos ornamentales. Características generales"

UNE 22171:1985 "Granitos ornamentales. Tamaño de grano"

UNE 22172:1985 "Granitos ornamentales. Absorción y peso específico aparente" (Anulada)

UNE 22173:1985 "Granitos ornamentales. Resistencia al desgaste por rozamiento"

UNE 22174:1985 "Granitos ornamentales. Resistencia a las heladas"

UNE 22175:1985 “Granitos ornamentales. Resistencia a la compresión” (Anulada)

UNE 22176:1985 “Granitos ornamentales. Resistencia a la flexión” (Anulada)

UNE 22177:1985 "Granitos ornamentales. Módulo elástico" 
UNE 22178:1985 “Granitos ornamentales. Microdureza Knoop"

UNE 22179:1985 "Granitos ornamentales. Resistencia al choque"

UNE 22180:1985 "Mármoles y Calizas ornamentales. Características generales"

UNE 22181:1985 "Mármoles y Calizas ornamentales. Clasificación"

UNE 22182:1985 "Mármoles y Calizas ornamentales. Absorción y peso específico aparente" (Anulada)

UNE 22183:1985 "Mármoles y Calizas ornamentales. Resistencia al desgaste por rozamiento"

UNE 22184:1985 "Mármoles y Calizas ornamentales. Resistencia a las heladas"

UNE 22185:1985 "Mármoles y Calizas ornamentales. Resistencia a la compresión” (Anulada)

UNE 22186:1985 "Mármoles y Calizas ornamentales. Resistencia a la flexión" (Anulada)

UNE 22187:1985 "Mármoles y Calizas ornamentales. Módulo elástico"

UNE 22188:1985 "Mármoles y Calizas ornamentales. Microdureza Knoop"

UNE 22189:1985 "Mármoles y Calizas ornamentales. Resistencia al choque"

UNE 22190:1998 "Productos de Pizarra para tejados inclinados y revestimientos"

Parte 1: Especificaciones de producto

Parte 2: Métodos de ensayo

Parte 3: Sistemas de colocación

(2) UNE-EN 12370:1999 "Métodos de ensayo para piedra natural. Determinación de la resistencia a la cristalización de sales" UNE-EN 12372:1999 "Métodos de ensayo para piedra natural. Determinación de la resistencia a flexión bajo carga concentrada" UNE-EN 12407:2001 "Métodos de ensayo para piedra natural. Estudio petrográfico"

UNE-EN 1925:1999 "Métodos de ensayo para piedra natural. Determinación del coeficiente de absorción de agua por capilaridad" UNE-EN 1926:1999 "Métodos de ensayo para piedra natural. Determinación de la resistencia a la compresión"

UNE-EN 1936:1999 “Métodos de ensayo para piedra natural. Determinación de la densidad real y aparente y de la porosidad abierta y total"

(3) Norma Básica de la Edificación: Acciones en la Edificación NBE AE 88.Ministerio de Obras Públicas y Urbanismo. 1988

(4) Roldán Fernández, A. "Notas para una climatología de Salamanca". Publicación K 20 del Instituto Nacional de Meteorología. Ministerio de Transportes, Turismo y Comunicaciones. Madrid 1987 